\title{
JOURNAL.RU
}

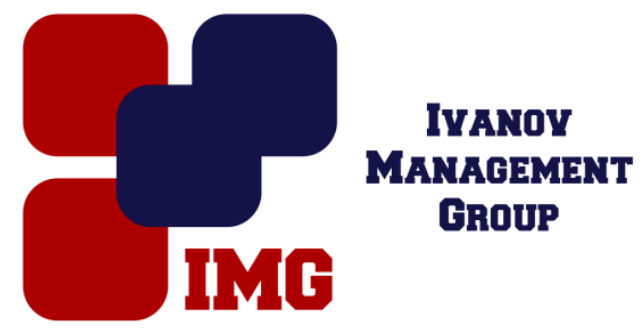

Макарова Е.Н.

Санкт-Петербургский университет МВД России Санкт-Петербург, Россия

doi: $10.18411 / 1 \mathrm{j}-30-06-2017-33$

idsp 000001:1j-30-06-2017-33

\section{Способы совершения угрозы причинения насилия потерпевшему как элемент криминалистической характеристики преступлений}

\begin{abstract}
Аннотация:
В статье рассматриваются способы совершения такой преступной угрозы, как угроза применения насилия в отношении потерпевшего; предлагается авторское понятие такой угрозы, рассматриваются ее виды. Тщательное изучение способов угроз поможет в расследовании таких преступлений, для которых выявление и доказывание угрозы является существенным обстоятельством для квалификации деяния (угроза убийством или причинением тяжкого вреда здоровью, угроза применения насилия опасного или не опасного для жизни и здоровья), а равно объективного установления обстоятельств, исключающих преступность и наказуемость деяния.

Ключевые слова: угроза применения насилия, способы угрозы применения насилия, угроза убийством, криминалистическая характеристика.

Доказывание способа угроз довольно сложный процесс, но имеет большое практическое значение, так как обстоятельства совершения таких деяний носят больше субъективный (восприятие угрозы потерпевшим, запугивание для упрощения достижения преступного результата виновным), а не объективный характер (общественно опасные последствия в виде реального причинения вреда жизни или здоровью не наступают). Это вызывает сложности в расследовании, отсутствие единого подхода и понятий угроз ведут к разнообразной практике применения, иногда приводит к исключению уголовной ответственности в связи
\end{abstract}


с недоказанностью состава преступления, либо, наоборот, ошибочное привлечение к ответственности лица, действующего в условиях необходимой обороны или крайней необходимости (например, когда следователь не должным образом проверяет версию о необходимой обороне и не доказывает имеющуюся фактически угрозу жизни).

Проблемами доказывания способов угроз занимались и занимаются многие ученые: Р.С. Белкин, М.В. Белов, В.С. Бурданова, И.Е. Быховский, И.А. Возгрин, В.А. Владимиров, Л.Д. Гаухман, Е.В. Никитин, С.В. Пархоменко, А.А. Радченко, М.В. Хабарова, Л.В. Сердюк и др.

Угроза применения насилия в уголовном праве предусмотрена во многих статьях Особенной части Уголовного кодекса Российской Федерации (далее УПК РФ) и может быть классифицирована на четыре группы: 1) угроза убийством или причинением тяжкого вреда здоровью (ст. ст. 119, п. «б» ч. 2 ст. 131, П. «б» ч. 2 ст. 132 УК РФ, ст. 296, ч. 2 ст. 309); 2) угроза применением насилия, опасного для жизни или здоровья (п. «в» ч. 2 ст. 126, ч. 1 ст. 162 , ч. 4 ст. 166 , п. «В» ч. 2 ст. 211 , п. «б» ч. 3 ст. 221 , п. «б» ч. 4 ст. 226, п. «В» ч. 3 ст. 229, ч. 3 ст. 313 УК РФ); 3) угроза применением насилия, не опасного для жизни или здоровья (П. «Г» ч. 2 ст. 161, П. «В» ч. 2 ст. 166 , П. «Г» ч. 2 ст. 221 , П. «Г» ч. 3 ст. 226, П. «Г» ч. 2 ст. 229, ч. 1 ст. 318, ч. 1 ст. 321 УК РФ); 4) угроза применением насилия (ст. ст. 120, п. «е» ч. 2 ст. 127.1, п. «г» ч. 2 ст. 127.2, ч. 1 ст. 131 , ч. 1 ст. 132 , ч. 2 ст. 139 , п. «а» ч. 2 ст. 141,ч. 2 ст. 142, ч. 2 ст. 144, П. «б» ч. 4 ст. 148 , ст. 149 , ч. 3 ст. 150 , ч. 3 ст. 151 , ч. 1 ст. 163 , ч. 3 ст. 170.1 , ч. 3 ст. 178, ч. 1 ст. 179 , ч. 2 ст. 185.5 , ч. 2 ст. 203 , ч. 1 ст. 227 , п. «Г» ч. 2 ст. 230 , п. «В» ч. 2 ст. 230.1, П. «а» Ч. 2 ст. 240, П. «б» ч. 2 ст. 241 , П. «в» Ч. 2 ст. 244, П. «а» ч. 2 ст. 282 , ч. 1 ст. 283.1 , п. «а» ч. 3 ст. 286 , ч. 3 ст. 322 , ч. 2 ст. 330 , ч. 1 ст. 333 УК PФ).

Угроза применения насилия в качестве способа совершения преступления облегчает достижение преступной цели виновным, значительно повышает степень общественной опасности совершаемого деяния, при этом анализ действующего уголовного законодательства позволяет констатировать, что для части квалифицирующих обстоятельств, благодаря степени угроз, увеличивается не только общественная опасность, но и изменяется ее характер [15, с. 435].

Так как в юридической литературе и уголовном законодательстве нет четкого определения угрозы, то и нет четкого определения ее признаков.

О.К. Зателепин выделяет общие (факт запугивания потерпевшего применением насилия и действительность угрозы применения насилия) и 
особенные (реальность, момент предполагаемой реализации угрозы, интенсивность угрозы) признаки угрозы применения насилия [6, с. 288].

А.В. Варданян выделяет три основных признака угрозы: наличность, реальность, непосредственность [5, с. 8, 9].

Бесспорно, необходимым свойством угрозы выступает ее реальность, под которой понимаются объективные основания опасения потерпевшим реальности реализации высказываемых виновным угроз [11, с. 6; 13, с. 6]. Этот признак предполагает необходимость следователя, дознавателя доказывать не только наличие самой угрозы, но и то, что она была «намеренно высказана с целью устрашения потерпевшего и в форме, дающей основания опасаться ее воплощения» $[1 ; 2]$.

Реальность опасности должна быть всесторонне исследована и доказана, особенно в части установления этапа совершения деяния. В частности следует установить, является ли угроза окончательным способом совершения преступления, либо это покушение на достижение общественно опасных последствий в виде причинения вреда жизни или здоровью. Поэтому подлежат выяснению как объективные, так и субъективные основания угрозы. К объективным основаниям относятся: 1)форма или способ угроз; 2) интенсивность конкретных действий, подкрепляющих угрозу, в том числе предшествующих или сопровождающих угрозу побоев, связывания, причинения легкого вреда, удержания и т.д.; 3) ситуация или сопутствующая обстановка (место, время, наличие или отсутствие посторонних); 4) личность угрожающего (прошлая судимость, вспыльчивый характер, устойчивая антиобщественная ориентация; склонность к проявлениям жестокости, агрессивности, бурные проявления злобы, ненависти, обиды, экстремальное психическое состояние; неумеренное употребление спиртных напитков); 5) предшествующие взаимоотношения виновного и потерпевшего (систематическое преследование потерпевшего, его унижение и издевательства над ним) и др. [12, с. 70, 7, с. 401]. К субъективным основаниям относятся: личность потерпевшего, нахождение в зависимости от виновного (должностное положение, родство, процессуальное положение участника уголовного судопроизводства и т.д.) [10, с. 45].

Второй признак угрозы: наличность. Данный признак является дискуссионным в уголовном праве $[13$, с. 6,$7 ; 5$, с. 7]. Это вызвано тем, что он характерен не для всех преступлений. Например, наличность является определяющим для квалификации деяний против половой свободы и половой неприкосновенности [3], при грабеже (ст. 161 УК РФ) и разбое (ст. 162 УК РФ), 
но для некоторых общественно опасных деяний не является определяющей (ст. ст. 119, 163, 333 УК РФ).

Вместе с тем, в литературе высказывается мнение о том, что угроза применения насилия в будущем также должна рассматриваться как элемент объективной стороны так как «вызывает те же эмоции страха, испуга и ужаса, которые способы не только подавить волю потерпевшей, но и причинить психическую травму» [8, с. 190, 191], а также принимает более «мягкую» форму противоправного принуждения, которое также обеспечивает достижение виновным преступного результата [4, с. 13].

Третьим признаком мы считаем общественную опасность угрозы, т.е. угроза должна быть направлена на охраняемый уголовным законом объект. Угроза может быть направлена не только на ее реализацию в виде причинения насилия потерпевшему, но также его близких родственников, родственников, близких лиц (если данный способ непосредственно указан в диспозиции статьи УК РФ).

Высказываемый признак в юридической литературе интенсивности психического насилия без посягательства на указанный объект исключит уголовную наказуемость деяния (например, угроза применения насилия не опасного ни для жизни, ни для здоровья), поэтому выделение такого признака не имеет юридической силы.

Способы угроз применения насилия разнообразны и могут быть классифицированы по различным основаниям. Интересны основания классификации таких угроз, представленные Е.Д. Пирожок [14, с. 12-14]. Так, в зависимости от формы выражения, выделяются: 1) простые угрозы, т.е. используемые субъектом преступления только одного, относительно самостоятельного вида угроз (словесная (вербальная), в том числе передаваемая через третьих лиц, письменная, высказываемая по телефону, передача в SMSсообщении, в сети Интернет); 2) комбинированный способ совершения угроз (словесная угроза, сопровождаемая демонстрацией оружия или иных предметов, используемых в качестве возможного орудия; с удержанием лица путем физического контакта с одеждой и частями тела потерпевшего; со «срезанием» с жертвы одежды; с ограничением свободы передвижения жертвы путем связывания рук или ног и т.д.).

О.И. Коростылёв представил иную группировку по способы выражения угрозы: вербальную, инвариантную, устную, письменную, конклюдентную, ситуационную, комбинированную [9, с. 7]. 
Также угрозы могут быть классифицированы в зависимости от времени предполагаемого исполнения: немедленной реализации (ст. 161, 162 УК РФ), угрозы реализации в будущем (ст. 163 УК РФ).

Таким образом, реальность, наличность и посягательство на охраняемый уголовным законом объект - это признаки угрозы, которые должны осознаваться не только потерпевшим, но и виновным. Т.е. следователь, дознаватель должен доказать, что виновный осознавал преступный характер высказываемых угроз, что его деяние имеет негативное психологическое воздействие на потерпевшего; он предвидел, что потерпевший из-за страха высказываемого насилия воспринимает угрозу как реальную и поменяет свое поведение, выполнив требования виновного; не желая реализации угроз, но осознавая реальность их совершения, стремился на достижение такого поведения потерпевшим, А потерпевший, в свою очередь, воспринимал высказываемые виновным угрозы как реальные и опасные для жизни или здоровья, опасался их реализации не зависимо от времени исполнения.

Предлагаем следующее определение: угроза применением насилия - это виновно совершенное умышленное воздействие на психику лица, выражающийся в демонстрации или высказывании субъективной решимости причинения вреда жизни или здоровью такому лицу (а в случаях, прямо предусмотренных уголовным законом - также его близким родственникам, родственникам, близким лицами), в условиях реальной возможности реализации применения такого насилия, и реально воспринимаемая потерпевшим. Цель угрозы является обязательной для квалификации не для всех составов, чаще всего - это понуждение к изменению поведения потерпевшего в интересах угрожающего лица, либо облегчение совершения иного преступления, либо по мотивам мести. 
1. Определение Конституционного Суда Российской Федерации от 23 марта 2010 г. № 368$\mathrm{O}-\mathrm{O}$ «Об отказе в принятии к рассмотрению жалобы гражданина Калугина Василия Викторовича на нарушение его конституционных прав частью первой статьи 119 и частью первой статьи 286 Уголовного кодекса Российской Федерации» [Электронный pecypc] // Законы, кодексы и нормативно-правовые акты Российской Федерации: http://legalacts.ru/doc/opredelenie-konstitutsionnogo-suda-rf-ot-23032010-n-368-o-o-ob - дата обращения 20.06.2017 г.

2. Постановление Пленума Верховного Суда РФ от 27 декабря 2002 г. № 29 «О судебной практике по делам о краже, грабеже и разбое» (с изменениями и дополнениями на 16.05.2017 г.) [Электронный ресурс] // СПС «Гарант» http://base.garant.ru/1352873/ - дата обращения 20.06.2017 г.

3. Постановление Пленума Верховного Суда РФ от 4 декабря 2014 г. № 16 «О судебной практике по делам о преступлениях против половой неприкосновенности и половой свободы личности» [Электронный ресурс] // СПС «КонсультантПлюс» http://www.consultant.ru/document/cons_doc_LAW_171782 - дата обращения 20.06.2017 г.

4. Безверхов А. понятие и виды насилия в уголовном праве России: вопросы правотворчества и правоприменения // Уголовное право. 2014. № 4. С. 11-18.

5. Варданян А.В. Насилие и угроза его применения как способ совершения преступлений против половой неприкосновенности и половой свободы личности // Известия Тульского государственного университета. Экономические и юридические науки. 2015. № 3-2. С. 39.

6. Зателепин О.К. Квалификация преступлений против военной безопасности государства: монография. Серия «Право в Вооруженных Силах - консультант». М.: За права военнослужащих. 2009. Вып. 106. - 288 с.

7. Комментарий к Уголовному кодексу Российской Федерации (постатейный) Бриллиантов А.В., Долженкова Г.Д., Иванова Я.Е. и др. / Под ред. А.В. Бриллиантова. М.: Проспект, 2010. $1031 \mathrm{c.}$

8. Котельникова Е.А., Шумихин В.Г. Разграничение насильственных и ненасильственных преступлений против половой свободы и половой неприкосновенности // Известия вузов. Правоведение. 2008. № 5. - С. 188-195.

9. Коростылёв О.И. Уголовно-правовая характеристика угрозы: Дис. ... канд. Юрид. наук (12.00.08). Ставрополь. 2004. - 163 с.

10. Кудрявцев В.Л. Объективная сторона преступления, предусмотренного ч. 1 ст. 302 УК РФ «Принуждение к даче показаний»: некоторые уголовно-правовые и уголовнопроцессуальные проблемы // Евразийская адвокатура. 2017. № 1. - С. 42-52.

11. Лукьянова И.В. Угроза как преступление в уголовном праве России: Дис. ... канд. Юрид. наук (12.00.08). - М., 2004. - 184 с.

12. Особенная часть Уголовного кодекса Российской Федерации: Комментарий. Судебная практика. Статистика / Под общ. ред. В.М. Лебедева, отв. ред А.В. Галахова. М., 2009. $1168 \mathrm{c}$.

13. Пархоменко С.В., Радченко А.А. Угроза как способ преступного воздействия на личность в процессе доказывания в российском судопроизводстве // Всероссийский криминологический журнал. 2009. № 3. - С. 5-10.

14. Пирожок Е.Д. Способ преступления как наиболее важный элемент криминалистической характеристики угрозы убийством или причинением тяжкого вреда здоровью // Российский следователь. 2013. № 2. - С. 11-14.

15. Фомичева М.А. Угроза как способ в квалифицированном составе преступления // Актуальные проблемы российского права. 2007. № 1. - С. 431-437. 